\section{Resistance Response of the $M a$ genes from 'Myrobalan' Plum to Meloidogyne hapla and M. mayaguensis}

\author{
Maria-Jose Rubio-Cabetas, Jean-Claude Minot, Roger Voisin, and \\ D. Esmenjaud ${ }^{1}$ \\ Unité 'Santé Végétale et Environnement', Institut National de la Recherche \\ Agronomique (INRA), B.P. 2078, 06606 Antibes Cedex, France
}

Georges Salesses and Abel Bonnet

Unité de Recherche sur les Espèces Fruitières et la Vigne, INRA, B.P. 81, 33883 Villenave d'Ornon Cedex, France

Additional index words. genetic control, Prunus cerasifera, root-knot nematode

\begin{abstract}
In 'Myrobalan' plum (Prunus cerasifera Ehr.), Ma1 and Ma2 are single major dominant genes that control the resistance to the predominant root-knot nematode (RKN) species Meloidogyne arenaria (Neal) Chitwood, M. incognita (Kofoid \& White) Chitwood, and $M$. javanica (Treub). These genes were evaluated for activity to the northern RKN $M$. hapla Chitwood and the tropical RKN M. mayaguensis Rammah \& Hirschmann, neither of which is controlled by the Mi gene from tomato. This study was conducted under greenhouse conditions using a resistance screening based on high and durable inoculum pressure by the nematodes. Tests were conducted simultaneously for: $M$. arenaria (as a reference for the $\mathrm{Ma}$ genes); $\mathrm{M}$. hapla and $\mathrm{M}$. mayaguensis from crosses segregating for either $M a 2$ alone or $M a 2$ and $M a 1$ and involving the resistant parental clones P.2175 (heterozygous for Ma1) and P.1079 (homozygous for Ma2); and the host parental clone P.2646 (recessive for both $M a$ genes). Each parental clone and each individual of the segregating progenies reacted in a similar way to $M$. arenaria and $M$. mayaguensis, indicating that the $\mathrm{Ma}$ genes also control resistance to M. mayaguensis. By contrast, all parental clones and progenies were completely resistant to $M$. hapla, and, despite high inoculum pressure, no effect of the $M a$ genes on this species could be established.
\end{abstract}

Root-knot nematodes (RKN) cause significant economic damage to Prunus crops in many countries (Kochba and Spiegel-Roy, 1976; Pinochet et al., 1989; Scotto La Massèse et al., 1984). The three most widely distributed species in the Mediterranean region are Meloidogyne arenaria, $M$. incognita, and $M$. javanica. Almond [P. amygdalus Batsch] and peach $[P$. persica (L.) Batsch] on susceptible rootstocks can be heavily damaged by Meloidogyne sp. in Mediterranean areas (Kester and Grasselly, 1987; Lamberti, 1979; Nyczepir, 1991; Pinochet et al., 1990). Resistant rootstocks are the best alternative to chemical control by using preplant fumigation, which is costly, short-lived, and may pollute the environment.

Diverse sources of resistance have been used (Kester and Grasselly, 1987). Among the subgenus Amygdalus (including the peach and almond species), the peach 'Nemaguard' and

Received for publication 23 Feb. 1999. Accepted for publication 1 June 1999. Part of this work was supported by a Research Training Grant (Contract FAIR-BM-96-0122) supplied by the European Union under the $4^{\text {th }}$ Research and Development Framework Programme (1994-98). The cost of publishing this paper was defrayed in part by the payment of page charges. Under postal regulations, this paper therefore must be hereby marked advertisement solely to indicate this fact.

${ }^{1}$ To whom reprint requests should be addressed (e-mail: esmenjau@antibes.inra.fr). the related 'Nemared' rootstocks express a near-complete resistance spectrum (Esmenjaud et al., 1997). Their resistance was overcome by one population detected in Florida, a new species thus designated $M$. sp. Florida (Esmenjaud et al., 1997; Rubio-Cabetas et al., 1999). Another source of RKN resistance is 'Myrobalan' plum, P. cerasifera (Scotto La Massèse et al., 1990), which belongs to the subgenus Prunophora (plum and apricot species), and no RKN population has yet overcome this resistance. Resistance to major RKN species in 'Myrobalan' plum is controlled by single dominant genes, termed the $M a$ genes. These genes confer a high-level and widespectrum resistance to the major RKN species $M$. arenaria, $M$. incognita, and $M$. javanica and also to the undescribed population $M$. sp. Florida (Esmenjaud et al., 1996; Lecouls et al., 1997). Consequently, they differ from the putative genes involved in the resistance of the Amygdalus subgenus and are of particular interest in breeding programs for new Prunus genes. rootstocks. Marker-assisted selection is in progress and one sequence characterized amplified region (SCAR) marker has recently been described (Lecouls et al., 1999).

Nevertheless, no study has been conducted on the response of these genes to the northern RKN, M. hapla, and to the tropical RKN, M. mayaguensis (Rammah and Hirshmann, 1988), both of which reproduce on tomatoes (Lycopersicon esculentum Mill.) carrying the Mi gene (Fargette at al., 1996; Hadisoeganda and Sasser, 1982). The species M. hapla, although it is of a temperate origin, can develop on various legume and horticultural crops in Mediterranean climates where it has been widely introduced. The species $M$. mayaguensis, distributed at least in Africa (Fargette et al., 1996) and in Central America (Rammah and Hirschmann, 1988), is highly aggressive and is a potential pest in southern Mediterranean regions in Prunus orchards planted for early fruit production. Our purpose was to determine the response of the $M a l$ and Ma2 genes to M. hapla and M. mayaguensis both for practical reasons and also to obtain basic knowledge of the resistance spectrum of both genes that might be introduced in a wider range of plant species using biotechnology.

\section{Material and Methods}

Plantmaterial. The three 'Myrobalan' plum parental clones, P.1079, P.2175, and P.2646, and appropriate crosses were chosen for this study. P.1079 and P.2175 are highly resistant to RKN and carry, respectively, the genes $M a 2$ (homozygous) and Mal (heterozygous) (Lecouls et al., 1997). The clone P.2646 (recessive for both genes) is a host for all tested RKN.

Intraspecific crosses involving the parents P.2175 and P.2646 and their progeny clones P.2175 x (P.2646 x P.1079)9 and P.2646 X (P.2646 X P.1079) 3 were used. All tested crosses segregate for resistance to $M$. arenaria, $M$. incognita, and $M$. javanica. Sixty individuals of P. $2175 \times$ (P.2646 x P.1079)9 (segregates for Mal and Ma2) and 10 of P.2646 X (P.2646 x P.1079)3 (segregates for Ma2) were evaluated (Table 1). The designations (P.2646 X P.1079) 9 and (P.2646 X P.1079) 3 are used to identify the individual selections 9 and 3 , respectively, from the cross between the female parent P.2646 and the male parent P.1079.

Nematode populations. Two RKN populations, $M$. hapla 'Canada' originally introduced from Canada and M. mayaguensis 'VSS1' originally introduced from Senegal, were used. Another population, $M$. arenaria 'Monteux', belonging to the RKN reference species, which was used to identify the $M a$

Table 1. Phenotype and genotype of parental clones for $M a$

\begin{tabular}{|c|c|c|}
\hline Clone & Phenotype $^{\mathrm{x}}$ & Genotype \\
\hline$\overline{P .2175}$ & $\mathrm{R}$ & Ma1 mal, ma2 ma2 \\
\hline P.1079 & $\mathrm{R}$ & mal ma1, Ma2 Ma2 \\
\hline P.2646 & $\mathrm{H}$ & mal ma1, ma2 ma2 \\
\hline (P.2646 x P.1079) 3 & $\mathrm{R}$ & mal ma1, Ma2 ma2 \\
\hline (P.2646 x P.1079) 9 & $\mathrm{R}$ & mal ma1, Ma2 ma2 \\
\hline
\end{tabular}


genes (Esmenjaud et al., 1996), was also included. All three cultures were isolates obtained from one single egg mass and maintained on tomato cv. Piersol, which has the $M i$ resistance gene (Roberts et al., 1990). The identity of the three RKN species was confirmed by electrophoresis patterns (Janati et al., 1982).

Evaluation of plant material. Parental and hybrid genotypes were propagated at the Institut National de la Recherche Agronomique (INRA), Villenave d'Ornon, France, from softwood cuttings collected from juvenile or adult trees. Cuttings $(25-\mathrm{cm}$ length, 5-mm diameter) were harvested either in May or in June. The cuttings were rooted individually in plates in the nursery up to late autumn to allow development of rooted plants, and shipped in December to the Laboratoire de Biologie des Invertebres at INRA, Antibes, France, for resistance evaluations during the following year. Cuttings were then repotted by pairs during winter into 5-L containers filled with a sandy substrate. All containers were then placed on iron benches in a greenhouse, and grown at a mean temperature of $25^{\circ} \mathrm{C}$ (extremes 22 to 28 $\left.{ }^{\circ} \mathrm{C}\right)$ until rating. In mid-March, tomato plantlets were planted into a sandy substrate in 250$\mathrm{mL}$ plastic containers in the same greenhouse. Juveniles, 24 to $72 \mathrm{~h}$ old, of the RKN species to be tested, were deposited, at the rate of 500/ pot, into two holes $2 \mathrm{~cm}$ deep and $2 \mathrm{~cm}$ from the plant stem. The level of inoculum was chosen based on a previous methodological study with $M$. arenaria 'Monteux' (Esmenjaud et al., 1992). Juveniles were obtained in a mist chamber from tomato roots previously inoculated with the same RKN species.

In mid-May, 2 months after inoculation, the tops of the tomato plants were removed and one entire tomato root system with the surrounding soil was transplanted into each Prunus container. Containers infested with the same Meloidogyne species were arranged in a completely randomized block design on a greenhouse bench. Groups of containers corresponding to different species were separated from each other with transparent splash screens. Each plant clone-RKN species combination was replicated six times (three containers with two cuttings each).

The 'Myrobalan' plants were harvested 4 months after inoculation. The roots of each plant were washed and given a root gall index (GI) rating according to a $0-5$ scale $(0=$ no gall; $1=1 \%$ to $10 \%$ of root system galled; $2=$ $11 \%$ to $30 \% ; 3=31 \%$ to $70 \% ; 4=71 \%$ to $90 \%$; $5>90 \%$ ), using 0.5 steps when galling was estimated to be intermediate between two categories. Extraction and counting of nematodes (Jenkins, 1964) were performed only on $12 \mathrm{Ma}$ segregating individuals. Since six replicates of each tested clone-RKN species combination were available, mean GI ratings were analyzed separately for each RKN species and each progeny (completed with the corresponding parental clones) using a one-way analysis of variance (ANOVA) (Noe, 1985). Then the clones were compared by the Newman-Keuls multiple range test at $P \leq 0.01$ for distribution into different classes.

\section{Results and Discussion}

Meloidogyne arenaria. For the reference species $M$. arenaria, parental clones P.2175, P.1079, (P.2646 x P.1079)3, and (P.2646 X P.1079)9 were quite free of galls and confirmed their high level of resistance(Esmenjaud et al., 1996). They were highly significantly separated $(P \leq 0.01)$ from the host parent P.2646. Mean GI ratings of the individuals of the segregating progenies, including parents, clearly separated two highly significantly different classes: the resistant $(\mathrm{R})$ class with clones with a GI $\leq 0.2$ and the host $(\mathrm{H})$ class grouping the host clones with a GI $>0.9$ (Table $2)$. No intermediate clones were observed. Thus, segregation of both progenies for $M a$ genes was confirmed. In the cross with the largest numbers, P.2175 x (P.2646 × P.1079)9, which involves the Mal and Ma2 genes, the segregation ratio was distorted (2R:1H instead of $3 \mathrm{R}: 1 \mathrm{H})$, but remained at an acceptable probability with the chi square test $(0.1<P<$ 0.2). In the cross P. $2646 \times$ (P.2646 X P.1079)3, the expected $1 \mathrm{R}: 1 \mathrm{H}$ ratio was observed, although the population size was very small.

Meloidogyne hapla. All of the parental clones, and particularly the $M a$ recessive clone P.2646, were highly resistant to M. hapla (Table 3). In the progenies tested, no segregation of resistance was observed. To strengthen these results, roots were carefully reexamined to locate eventual minor galls that could have escaped the first rating observation and might indicate initiation of a nematode feeding site (NFS), but no symptoms were observed. In addition, nematode extraction from the roots of 12 individuals segregating for $M a(6 \mathrm{R}$ and $6 \mathrm{H}$ ) recovered no second-stage juveniles (data not shown). Additionally, 26 individuals ( $8 \mathrm{R}$ and $18 \mathrm{H}$ to $M$. arenaria) from another segregating cross (P.16.5 x (P.16.5 x P.1079)29, involving another $M a$ recessive clone (P.16.5), were also evaluated for resistance to M. hapla (data not shown). This complementary work was justified because clone P.16.5 is a better host for M. arenaria and thus may be a better host for M. hapla. No symptoms and no NFS were detected on any root system.

Meloidogyne hapla does not reproduce on 'Myrobalan' plum. Our work on this RKN was aimed at favoring nematode development or gall formation by using a high and durable inoculum pressure and to determine any difference, even minor, between Prunus material segregating for $M a$. Because plant symptoms that could have indicated the initiation of a NFS were not observed, one cannot draw conclusions on the activity of the $M a$ genes against $M$. hapla. 'Myrobalan' plum may be a non-host plant for M. hapla, which means that many unfavorable genetic factors prevent the penetration and the development of this RKN and hide the putative expression of the $M a$

Table 2. Distribution in 'Myrobalan' plum of two progenies [P.2175 x (P.2646 X P.1079) 9 and P.2646 X (P.2646 x P.1079) 3] segregating for the $M a 1$ and $M a 2$ genes for resistance to $M$. arenaria on a $0-5$ gall index (GI) rating.

\begin{tabular}{|c|c|c|c|c|c|c|c|}
\hline \multirow[b]{3}{*}{ Clone } & \multirow{3}{*}{$\begin{array}{l}\text { No. hybrid } \\
\text { genotypes }\end{array}$} & \multicolumn{4}{|c|}{ Gall index } & \multirow[b]{3}{*}{$\chi^{2}$} & \multirow[b]{3}{*}{$P$-value } \\
\hline & & \multicolumn{2}{|c|}{ Observed } & \multicolumn{2}{|c|}{ Expected ratio $^{z}$} & & \\
\hline & & $\overline{\mathrm{R}^{\mathrm{y}}(\leq 0.2)}$ & $\mathrm{H}(>0.9)$ & $\mathrm{R}$ & $\mathrm{H}$ & & \\
\hline P.2175 & & $\mathrm{x}$ & & & & & \\
\hline P.1079 & & $\mathrm{x}$ & & & & & \\
\hline P.2646 & & & $\mathrm{x}$ & & & & \\
\hline (P.2646 x P.1079) 9 & & $\mathrm{x}$ & & & & & \\
\hline (P.2646 x P.1079) 3 & & $\mathrm{x}$ & & & & & \\
\hline P. $2175 \times($ P.2646 $\times$ P.1079) 9 & 60 & 40 & 20 & 47.25 & 15.75 & 2.3 & $0.1-0.2$ \\
\hline P.2646 X (P.2646 x P.1079) 3 & 10 & 4 & 6 & 5 & 5 & 0.4 & $0.5-0.6$ \\
\hline
\end{tabular}

${ }^{\mathrm{z}}$ Based on the hypothesis presented in Table 1.

${ }^{\mathrm{y}} \mathrm{R}=$ resistant; $\mathrm{H}=$ host; $\mathrm{R}$ and $\mathrm{H}$ classes were determined by ANOVA $(P \leq 0.01)$.

Table 3. Resistance of parental clones to M. arenaria (MA), M. mayaguensis (MM), and M. hapla (MH) and distribution of 'Myrobalan' plum crosses segregating for Mal and Ma2 genes and simultaneously tested for resistance to these three RKN species.

\begin{tabular}{|c|c|c|c|c|}
\hline \multirow[b]{2}{*}{ Clones } & \multirow{2}{*}{$\begin{array}{c}\text { Genes } \\
\text { involved }\end{array}$} & \multicolumn{3}{|c|}{ No. and distribution of clones evaluated for: } \\
\hline & & MA & MM & MH \\
\hline$\underline{\text { Parents }}$ & & \multicolumn{3}{|c|}{ Resistance } \\
\hline P.2175 & & $\mathrm{R}^{\mathrm{z}}$ & $\mathrm{R}$ & $\mathrm{R}$ \\
\hline P.1079 & & $\mathrm{R}$ & $\mathrm{R}$ & $\mathrm{R}$ \\
\hline P.2646 & & $\mathrm{H}$ & $\mathrm{H}$ & $\mathrm{R}$ \\
\hline (P.2646 x P.1079) 3 & & $\mathrm{R}$ & $\mathrm{R}$ & $\mathrm{R}$ \\
\hline (P.2646 x P.1079) 9 & & $\mathrm{R}$ & $\mathrm{R}$ & $\mathrm{R}$ \\
\hline Tested crosses & & \multicolumn{3}{|c|}{ No. of clones } \\
\hline P.2646 x (P.2646 x P.1079) 3 & $M a 2$ & & & \\
\hline $\mathrm{R}$ & & 4 & 4 & 10 \\
\hline $\mathrm{H}$ & & 6 & 6 & 0 \\
\hline P.2175 x (P.2646 x P.1079) 9 & $M a 1$ and $M a 2$ & & & \\
\hline $\mathrm{R}$ & & 40 & 40 & 60 \\
\hline $\mathrm{H}$ & & 20 & 20 & 0 \\
\hline \multicolumn{5}{|l|}{ Total } \\
\hline $\mathrm{R}$ & & 44 & 44 & 70 \\
\hline $\mathrm{H}$ & & 26 & 26 & 0 \\
\hline
\end{tabular}

${ }^{2} \mathrm{R}=$ resistant $; \mathrm{H}=$ host $; \mathrm{R}$ and $\mathrm{H}$ classes were determined by ANOVA $(P \leq 0.01)$. 
genes. Considering that this non-host status is polygenic, circumventing this status might only be possible by considerable modification of the genetic background of 'Myrobalan' plum by repeated backcrosses to a host species. As most Prunus species are either poor or non-hosts, such a procedure appears practically impossible to perform currently.

Meloidogyne mayaguensis. In comparing $M$. arenaria vs. M. mayaguensis, all the individuals behaved in a similar way (Table 3 ). Whatever the RKN species to which they were exposed, the 60 individuals from the first progeny and the 10 individuals from the second progeny reacted identically to both species ( $R$ or $\mathrm{H})$. In other words, all individuals classified as resistant to $M$. arenaria were also classified as resistant to $M$. mayaguensis and all individuals classified as host to $M$. arenaria were also classified as host to M. mayaguensis.

This identical resistance behavior to $M$. arenaria and $M$. mayaguensis indicates that the $M a$ genes also control resistance to both RKN species. Consequently, the spectrum of these genes, which already control resistance to the major species of the polyphagous RKN complex, also extends to this minor species. Nematode introduction from tropical and equatorial countries, and especially from Africa where it develops on $M i$-resistant tomatoes and is generally very aggressive (Fargette, 1987; Fargette et al., 1996), into Prunus growing regions should not be a concern for growers using Prunus rootstock material carrying the $M a$ genes. Our data on this RKN species show that the genetic systems involved in tomato ( $M i$ gene) and 'Myrobalan' plum ( $M a$ genes) are not related. This result is not surprising considering that $\mathrm{RKN}$ resistance genes generally have been very specific (Roberts, 1995; Williamson and Hussey, 1996), and that their respective botanical families (Rosaceae and Solanaceae) are very distant from each other.

\section{Literature Cited}

Esmenjaud, D., J.C. Minot, R. Voisin, A. Bonnet, and G. Salesses. 1996. Inheritance of resistance to the root-knot nematode Meloidogyne arenaria in 'Myrobalan' plum. Theor. Appl. Genet. 92:873-879.

Esmenjaud, D., J.C. Minot, R. Voisin, J. Pinochet, M.H. Simard, and G. Salesses. 1997. Differential response to root-knot nematodes in Prunus species and correlative genetic implications. J. Nematol. 29:370-380.

Esmenjaud, D., C. Scotto La Massese, G. Salesses, J.C. Minot, and R. Voisin. 1992. Method and criteria to evaluate resistance to Meloidogyne arenaria in Prunus cerasifera Ehr. Fund. Appl. Nématol. 15:385-389.

Fargette, M. 1987. Use of the esterase phenotype in the taxonomy of the genus Meloidogyne. 2. Esterase phenotypes observed in West African populations and their characterization. Rev. Nematol. 10:45-56.

Fargette, M., M.S. Phillips, V.C. Block, R. Waugh, and D.L. Trudgill. 1996. An RFLP study of relationships between species, populations, and resistance breaking lines of tropical Meloidogyne.Fund. Appl. Nématol. 19:193-200.

Hadisoeganda, W.W. and J.N. Sasser. 1982. Resistance of tomato, bean, southern pea, and garden pea cultivars to root-knot nematodes based on host suitability. Plant Dis. 66:145-150.

Janati, A., J.B. Bergé, A.C., Triantaphyllou, and A. Dalmasso. 1982. Nouvelles données sur l'utilisation des isoestérases pour l'identification des Meloidogyne. Rev. Nématol. 5:147-154.

Jenkins, W.R. 1964. A rapid centrifugal flotation technique for separating nematodes from soil. Plant Dis. Rptr. 48:692.

Kester, D.E., and C. Grasselly. 1987. Almond rootstocks, p. 265-293. In: R.C. Rom and R.F. Carlson (eds.). Rootstocks for fruit crops. Wiley, New York.

Kochba, J.P. and P. Spiegel-Roy. 1976. 'Alnem 1', 'Alnem 88', 'Alnem 201' almonds: Nematoderesistant rootstock seed source. HortScience 11:270.

Lamberti, F. 1979. Economic importance of Meloidogyne spp. in subtropical and Mediterranean climates, p. 342-357. In: F. Lamberti and C.E. Taylor (eds.). Root-knot nematodes (Meloidogyne species): Systematics, biology and control. Academic Press, New York.

Lecouls, A.C., M.J. Rubio-Cabetas, J.C. Minot, R. Voisin, A. Bonnet, G. Salesses, E. Dirlewanger, and D. Esmenjaud. 1999. RAPD and SCAR markers linked to the Mal root-knot nematode resistance gene in 'Myrobalan' plum (Prunus cerasifera Ehr.). Theor. Appl. Genet. 99:328-335.
Lecouls, A.C., G. Salesses, J.C. Minot, R. Voisin, A. Bonnet, and D. Esmenjaud. 1997. Spectrum of the $M a$ genes for resistance to Meloidogyne spp. in 'Myrobalan' plum. Theor. Appl. Genet. 95:1325-1334.

Noe, J.P. 1985. Analysis and interpretation of data from nematological experiments, p. 187-197. In: K.R. Barker, C.C. Carter, and J.N Sasser. (eds.). An advanced treatise on Meloidogyne. Vol. II. Methodology. North Carolina State Univ. Graphics, Raleigh.

Nyczepir, A.P. 1991. Nematode management strategies in stone fruits in the United States. J. Nematol. 23:334-341.

Pinochet, J., J. Marull, S. Verdejo, and A. Soler. 1990. La seleccion de patrones de almendro, melocotonero e hibridos de melocotonero $x$ almendro frente a nematodos agalladores, Meloidogyne spp. Fruticult. Professional 29:2227.

Pinochet, J., S. Verdejo, and J. Marull. 1989. Evaluacion de siete patrones de Prunus a tres especies de Meloidogyne en Espana. Nematropica 19:125-134.

Rammah, A. and H. Hirschmann. 1988. Meloidogyne mayaguensis $\mathrm{n}$. sp. (Meloidogynidae), a rootknot nematode from Puerto Rico. J. Nematol. 20:58-69.

Roberts, P.A. 1995. Conceptual and practical aspects of variability in root-knot nematodes related to host plant resistance. Annu. Rev. Phytopathol. 33:199-221.

Roberts, P.A., A. Dalmasso, G.B. Cap, and P. Castagnone-Sereno. 1990. Resistance in Lycopersicumperuvianum to isolates of Migenecompatible Meloidogyne populations. J. Nematol. 22:585-589.

Rubio-Cabetas, M.J., G. Salesses, A.C. Lecouls, and D. Esmenjaud. 1999. Genetic control for resistance to root-knot nematodes in Prunus rootstocks. Acta Hort. (In press.)

Scotto La Massese, C., D. Esmenjaud, J.C. Minot, and R. Voisin. 1990. Host suitability in the genus Prunus to Meloidogyne arenaria, particularly clones and intraspecific hybrids of $P$. cerasifera. Acta Hort. 283:275-284.

Scotto La Massese, C., C. Grasselly, J.C. Minot, and R. Voisin. 1984. Différence de comportement de 23 clones et hybrides de Prunus à l'égard de quatre espèces de Meloidogyne. Rev. Nématol. 7:265-270.

Williamson, V.M. and R.S. Hussey. 1996. Nematodes pathogenesis and resistance in plants. Plant Cell. 8:1735-1745. 